Cornell University Law School

Scholarship@Cornell Law: A Digital Repository

$12-1-2019$

\title{
Challenging H-1B Denials in Federal Courts: Trends and Strategies
}

Hun Lee

Cornell Law School, hl2346@cornell.edu

Stephen W. Yale-Loehr

Cornell Law Schol, SWY1@cornell.edu

Follow this and additional works at: https://scholarship.law.cornell.edu/facpub

Part of the Immigration Law Commons, and the Litigation Commons

\section{Recommended Citation}

Lee, Hun and Yale-Loehr, Stephen W., "Challenging H-1B Denials in Federal Courts: Trends and Strategies" (2019). Cornell Law Faculty Publications. 1721.

https://scholarship.law.cornell.edu/facpub/1721

This Article is brought to you for free and open access by the Faculty Scholarship at Scholarship@Cornell Law: A Digital Repository. It has been accepted for inclusion in Cornell Law Faculty Publications by an authorized administrator of Scholarship@Cornell Law: A Digital Repository. For more information, please contact jmp8@cornell.edu. 


\title{
Challenging H-1B Denials in Federal Courts: Trends and Strategies
}

\author{
By Hun Lee and Stephen Yale-Loehr
}

\section{Introduction}

The denial rate for $\mathrm{H}-1 \mathrm{~B}$ petitions has quadrupled over the past few years, increasing from six percent in fiscal year (FY) 2015 to twenty-four percent in FY 2018. ${ }^{1}$ After President Trump issued his "Buy American and Hire American" executive order in April 2017, ${ }^{2}$ U.S. Citizenship and Immigration Services (USCIS) has effectively raised the standard of proof on H-1B petitions. ${ }^{3}$

USCIS has used several reasons to deny $\mathrm{H}-1 \mathrm{~B}$ petitions, including claims that the employer failed to show that a position qualifies as a "specialty occupation," impermissibly assigned employees to third-party worksites, or failed to pay the required wage. ${ }^{4}$

Under USCIS's recent approach, many H-1B petitioners are virtually faced with a "preordained denial" 5 regardless of how well they respond to requests for evidence (RFEs) or appeal their denial to the USCIS Administrative Appeals Office (AAO). More and more H-1B petitioners have challenged the legality of H-1B denials by filing complaints in federal court. Many have succeeded in getting their $\mathrm{H}-1 \mathrm{~B}$ denials reversed.

We have compiled a spreadsheet of over fifty federal court cases brought against USCIS in the last

1 National Foundation for American Policy, $H-1 B$ Denial Rates: Analysis of H-1B Data for First Three Quarters of FY 2019 at 1 (Oct. 2019), https://nfap.com/wp-content/ uploads/2019/10/H-1B-Denial-Rates-Analysis-of-FY-2019Numbers.NFAP-Policy-Brief.October-2019.pdf.

${ }^{2}$ White House, Presidential Executive Order on Buy American and Hire American (Apr. 18, 2017), https://www. whitehouse.gov/presidential-actions/presidential-executiveorder-buy-american-hire-american/.

${ }^{3}$ National Foundation for American Policy, supra note 1 , at 2 .

${ }^{4}$ Cyrus D. Mehta \& Eleyteria Diakopoulos, Fearlessly Challenging H-1B Visa Denials Through Litigation, ТнЕ Insightful Immigration Blog (Mar. 31, 2018), http://blog. cyrusmehta.com/2018/03/fearlessly-challenging-h-1b-visadenials-through-litigation.html.

5 Id. two years concerning H-1B denials. This article presents the litigation trends we have observed and offers strategies for immigration attorneys considering litigation to challenge an H-1B denial.

The bottom line: sue!

\section{Research Methodology and Results}

We used Bloomberg Law to identify H-1B complaints filed in federal court between late 2017 and October 2019. We clicked on "Docket" under "Research Tools," and entered "H-1B" on the Keywords box. We limited the search to federal district court dockets. We filtered the search results by selecting "Complaint/ Petition" from the dropdown list on the left under Filing Type. We went through the search results and entered cases into a spreadsheet as appropriate. The spreadsheet is available on Dropbox. ${ }^{6}$

As of mid-November 2019, the spreadsheet contains over fifty H-1B complaints. Cases are sorted in alphabetical order by the plaintiff's name. Plaintiffs in green indicate pending cases (subscribed to weekly docket updates). Those in orange indicate cases for which opinions were published; those in dark red indicate cases for which complaints are unavailable due to the party's non-consent.

The "Issue" column summarizes the legal issue raised by the plaintiffs, with a citation to the relevant statutory or regulatory provision where applicable. The issue also addresses the main grounds for the H-1B denial. Where the case focused on specialty occupation, the petitioner's position was entered under the "Specialty Occupation" column. The "AAO Appeal?" column notes whether plaintiffs filed an administrative appeal before suing in federal court.

The "USCIS Actions" column describes USCIS's actions leading up to the complaint, mostly noting

\footnotetext{
${ }^{6} \mathrm{https}: / /$ www.dropbox.com/s/9i8mgjeddnytk21/H-1B $\% 20$ Litigation $\% 20$ Spreadsheet.xlsx? $\mathrm{dl}=0$.
} 
whether USCIS had issued an RFE. The "Disposition" column first notes whether the case is pending or closed, and then summarizes the most recent development of the case. The "Comments" column mentions whether there were any noteworthy procedures such as filing an amended complaint, a motion for summary judgment, or a stay request.

The spreadsheet also notes when a complaint is not accessible on Bloomberg. ${ }^{7}$ Any description in red indicates something that is unique and not widely observed in other cases.

\section{Trends and Patterns}

Below are some trends and patterns that we observed:

\section{Procedural Observations}

Most plaintiffs did not file an administrative appeal before suing in federal court. Most plaintiffs had also received a RFE from USCIS before their H-1B denial. The most common structure of the complaints followed this order: (1) introduction; (2) jurisdiction; (3) venue; (4) standing; (5) exhaustion of remedies; (6) parties; (7) legal background; (8) factual allegations; (9) cause of action; and (10) request for relief. The "Hyperlink to Docket" column on the spreadsheet provides a link to the webpage where one can view activities in a docket and access the complaint.

\section{Substantive Observations}

Out of the fifty-two cases, forty involved H-1B denials based on an alleged failure to establish that the position was a "specialty occupation" under 8 C.F.R. $\$ 214.2(\mathrm{~h})(4)\left(\right.$ iii)(A). ${ }^{8}$ Grounds for denial in four other cases included an alleged failure to meet the minimum wage requirement, being employed at a third-party worksite, absence of an employer-employee relationship, failure to prove sufficient amount of work to perform throughout the requested period, and failure to maintain F-1 status before the H-1B petition. Three cases did not involve $\mathrm{H}-1 \mathrm{~B}$ denials. In those cases, the

7 Any complaint unavailable on Bloomberg is also unavailable on PACER.

${ }^{8}$ For a general discussion of the regulatory requirements to establish that a position is a "specialty occupation," see Charles Gordon, Stanley Mailman, Stephen Yale-Loehr \& Ronald Y. Wada, Immigration Law and Procedure §20.08[3] (rev. ed. 2019). plaintiffs alleged respectively that USCIS: failed to take action on a timely motion to reopen; ${ }^{9}$ unlawfully approved the $\mathrm{H}-1 \mathrm{~B}$ petition for a shorter duration than warranted; ${ }^{10}$ and failed to take action after the AAO's reversal of the $\mathrm{H}-1 \mathrm{~B}$ denial. ${ }^{11}$ The remaining five cases could not be classified because the complaints were inaccessible.

When denying an $\mathrm{H}-1 \mathrm{~B}$ petition for failure to establish that the position qualified as a specialty occupation, USCIS generally grounds its denial on all four criteria under 8 C.F.R. $\$ 214.2(\mathrm{~h})(4)($ iii)(A). In a number of cases, USCIS interpreted "bachelor's degree or higher in a specific specialty" (meaning "a range of educational degrees" that encompass closely related fields of study) as requiring a "bachelor's degree or higher in a specific field of study" (meaning "a unitary educational degree"). That effectively requires proving a single degree giving employees the skills necessary to complete their duties. In other cases, USCIS also concluded that a position does not "normally" require a bachelor's degree or higher, even when the Department of Labor's (DOL's) Occupational Outlook Handbook $(\mathrm{OOH})$ provides that "most" people in that position have a bachelor's degree or higher.

Software engineer and data analyst positions were the most common positions among the forty cases in this category, meaning that employers in the information technology sector are particularly impacted by the recent rise in $\mathrm{H}-1 \mathrm{~B}$ denials. ${ }^{12}$

\section{Selected Court Decisions}

Out of the fifty-two cases, twenty-three closed upon a voluntary dismissal, mostly by plaintiffs. Some of the attorneys involved in these cases informed us that USCIS reopened the cases in response to the lawsuit,

9 D'Aquila Advisors, LLC v. USCIS.

${ }^{10}$ ITserve Alliance, Inc. v. USCIS.

11 McKinsey \& Company, Inc. v. USCIS

12 In FY 2018, USCIS denied fifty-three percent of H-1B petitions of six information technology services companies for initial employment. In contrast, in FY 2018 USCIS denied only about one percent of $\mathrm{H}-1 \mathrm{~B}$ petitions filed by six major U.S. tech companies. Stuart Anderson, IT Services Companies and Clients Bear Brunt of H-1B Crackdown, ForBes (Feb. 25, 2019), https://www.forbes.com/sites/stuartanderson/2019/02/25/it-services-companies-and-clients-bearbrunt-of-h-1b-crackdown/\#79c175815415. 
after which it issued a second RFE before reversing its denial and approving the $\mathrm{H}-1 \mathrm{~B}$ petition. ${ }^{13}$

In ten cases, the plaintiff filed a motion for summary judgment. Of those, two were granted and three were denied. Summarized below are the decisions in those cases. Two of the three cases that USCIS won were in district courts in California.

\section{Decisions for H-1B Plaintiffs}

Raj \& Co. v. USCIS: ${ }^{14}$ The court held that USCIS abused its discretion by impermissibly narrowing the plain language of the statute by requiring a single specifically tailored and titled degree when determining that "although a baccalaureate level of training is typical, the position of a Market Research Analyst is an occupation that does not require a baccalaureate level of education in a specific specialty as a normal, minimum for entry into the occupation." 15 The court pointed to evidence in the record that the proffered position required a specialized degree in "market research" or an equivalent technical degree, accompanied by relevant coursework in "statistics, research methods, and marketing" as a minimum for entry. The court noted that "while judicial review of agency decisions is highly deferential, it is not without teeth. Agency action cannot survive judicial review where the agency fails to 'articulate a satisfactory explanation for its action including a rational connection between the facts found and the choice made." "16 In brief, the court did not agree with USCIS's interpretation that a specialty occupation requires some sort of an occupation-specific degree.

13 The attorney for Everymarket emailed us that USCIS reopened and approved the company's H-1B petition a few weeks after Everymarket filed its complaint. The attorney for Populus Group, LLC also noted that after the company sued, USCIS reopened its case and issued a second RFE. Similarly, the attorney for Preferred Population Health Management, LLC noted that USCIS asked for an extension after complaint was filed, issued a harmless RFE, and then approved the H-1B petition. Other immigration attorneys have observed that many times, USCIS reopens the denial and approves the case or issues another RFE after plaintiffs file a complaint in federal court. See Cyrus D. Mehta \& Gianna Boccanfuso, Denial of H-1B Cases: The Occupational Outlook Handbook is Not the Holy Grail, The Insightful Immigration Blog (Oct. 15, 2019), http://blog.cyrusmehta.com/2019/10/denialof-h-1b-cases-the-occupational-outlook-handbook-is-not-theholy-grail.html.

${ }^{14}$ Raj \& Co. v. USCIS, 85 F. Supp. 3d 1241 (W.D. Wash. 2015).

15 Id. at 1247.

16 Id. at 1248 .
RELX, Inc. v. Baran: ${ }^{17}$ The court held that USCIS acted arbitrarily and capriciously in determining that the offered position of data analyst under the occupational title of business intelligence analysts was not a specialty occupation solely on the fact that $\mathrm{OOH}$ did not contain a detailed profile for the position and that the use of DOL's Occupational Information Network (O*NET) failed to establish the occupation as a specialty occupation. The court pointed out that the $\mathrm{OOH}$ provided the information needed to classify the position as a specialty occupation and contained the O*NET cross reference, therefore holding that USCIS' denial was "factually inaccurate and not supported by the record." 18 Furthermore, in response to USCIS' claim that the offered position was not specialized because multiple fields of education appear to be acceptable for entry into the position, the court stated that "there is no requirement in the statute that only one type of degree be accepted for a position to be specialized."19 Also critical to the court's holding was the fact that USCIS reopened the H-1B petition and issued a second RFE (essentially the same as its previous RFE) shortly after the lawsuit was filed, after which USCIS filed a motion to dismiss on grounds that it had reopened the case. The court concluded that the government's failure to set forth its reasons for reopening the case and requesting the same evidence constituted arbitrary and capricious action. ${ }^{20}$

\section{Decisions Against H-1B Plaintiffs}

Altimetrik Corp. v. USCIS: ${ }^{21}$ The employer challenged five separate H-1B denials in the same lawsuit. The court agreed with USCIS that the plaintiff was employing the beneficiary as a systems analyst even though the position in the H-1B petition was for a software developer. USCIS concluded that the duties matched those of a systems analyst and thus referred to the $\mathrm{OOH}$ entry for systems analysts, for which "a bachelor's degree in a computer or information science field is common, although not always a requirement." 22 The court also agreed with USCIS that the duties were neither complex and unique under the second criterion,

17 RELX, Inc. v. Baran, 2019 U.S. Dist. LEXIS 130286 (D.D.C. Aug. 5, 2019).

18 Id. at $* 27$.

19 Id. at $* 28$.

20 Id. at $* 13-23$.

21 Altimetrik Corp. v. USCIS, 2019 U.S. Dist. LEXIS 168192 (E.D. Mich. Sept. 30, 2019).

22 Some attorneys comment that USCIS strategically switches occupations to apply more favorable educational requirements to find that there is no specialty occupation. 
nor specialized and complex under the fourth criterion. Finally, the court agreed with USCIS that the plaintiff failed to prove that the client entity required a bachelor's degree for the proffered position and that the beneficiary would perform actual duties requiring the skills of someone with a bachelor's degree or higher. ${ }^{23}$ Critical to the court's holding was the fact that the plaintiff failed to prove continuing employment, as the beneficiary was assigned to a project that had terminated, and that the description of a second project did not align with the listed duties.

Innova Solutions, Inc. v. Baran: ${ }^{24}$ The court agreed with USCIS that the plaintiff's position of programming analyst, falling under the OOH's computer programmer classification, did not satisfy the requirements of a specialty occupation. The court stated that the first criterion hinges on whether a bachelor's degree is required for entry into the occupation. The court held that the plaintiff could not rely on the $\mathrm{OOH}$ description for the computer programmer occupation, which states that "most" computer programmers have a bachelor's degree but that "some" employers hire workers with an associate's degree, because this profile does not provide the normal minimum educational requirements for the occupation. In other words, the court interpreted the $\mathrm{OOH}$ description that "some" workers have an associate's degree as showing that the position does

23 In Defensor v. Meissner, 201 F.3d 384 (5th Cir. 2000), the Fifth Circuit considered the client entity as the employer rather than the petitioner. USCIS uses Defensor to reject claims by employers that they hire others with the same educational credentials, even where they can show that they are the actual employers who control the employment. This is problematic because an $\mathrm{H}-1 \mathrm{~B}$ petition cannot be filed by the petitioning entity if the client is the actual employer and not the petitioner.

24 Innova Solutions, Inc. v. Baran, 2019 U.S. Dist. LEXIS 134790 (N.D. Cal. Aug. 8, 2019). This case concerned the H-1B denial of Mr. Dodda, one of the three beneficiaries at issue in the action brought by Innova. In an earlier decisionInnova Solutions Inc. v. Baran, 338 F. Supp. 3d 1009 (N.D. Cal. 2018) - the court adjudicated the claims regarding Mr. Gogumalla, whose H-1B denial was upheld when the court found that the $\mathrm{OOH}$ does not require a degree only in a specific specialty for the beneficiary's position.

The most recent $\mathrm{H}-1 \mathrm{~B}$ decision involving Innova was Innova Solutions, Inc. v. Baran, 2019 U.S. Dist. LEXIS 193297 (C.D. Cal. Nov. 5, 2019), which involved a different issue. The beneficiary, Mr. Alagarsamy, was not one of the three beneficiaries in the original action, and USCIS denied his H-1B petition based on a lack of an on-site employeremployee relationship. The court reversed USCIS's decision, finding that USCIS based its denial on the argument that Innova's website failed to prove that Innova created its own products in-house. The court held that USCIS disregarded evidence submitted by Innova that could establish that there was an on-site employer-employee relationship. not "normally require a baccalaureate degree or higher," implicitly equating "normal" to mean "always." The court also determined that the plaintiff failed to satisfy the other three criteria.

Liu v. USCIS: $:^{25}$ The court agreed with USCIS that the plaintiff's position of meeting, convention, or event planner is an occupation that does not require a baccalaureate level of education in a specific specialty as a normal minimum requirement. The court agreed with USCIS's finding that because the $\mathrm{OOH}$ states that "other common fields of study include communications, business, and business management" but does not mention a particular course work as an essential requirement, there was a rational basis for USCIS's conclusion that the position did not require a degree in a specific specialty.

Interestingly, before reaching this conclusion, the court acknowledged that district courts are split on whether the OOH's language that "some" positions do not require a bachelor's degree provides a rational connection to finding that the position is not a specialty occupation. The court noted that some courts interpret such $\mathrm{OOH}$ language as providing a rational connection to the finding that the position does not "normally" require a bachelor's degree or its equivalent (i.e. "normally" would mean "always"), ${ }^{26}$ whereas other courts interpret the OOH's language that "most" have a bachelor's degree as failing to provide a rational connection to the finding that the position does not "normally" require a bachelor's degree. ${ }^{27}$ The court also determined that the plaintiff failed to satisfy the other three criteria.

\section{Strategies and Takeaways}

The following are some takeaways from these observations, which in turn can serve as strategic guidance for attorneys with clients facing H-1B denials.

Do not appeal to the AAO. The AAO generally will uphold USCIS's denial, and may issue a stronger denial decision than the original USCIS denial. Instead, go straight to federal court. ${ }^{28}$

${ }^{25}$ Liu v. Baran, 2018 U.S. Dist. LEXIS 222796 (C.D. Cal. Dec. 21, 2018).

${ }^{26}$ See, e.g., Ajit Healthcare Inc. v. United States Dep't of Homeland Sec., 2014 U.S. Dist. LEXIS 186258, at *4 (C.D. Cal. Feb. 7, 2014).

27 See, e.g., Next Generation Tech., Inc. v. Johnson, 328 F. Supp. 3d 252, 267 (S.D.N.Y. 2017).

${ }^{28}$ See generally Diane M. Butler, Leslie K. Dellon, David Isaacson \& Stephen Yale-Loehr, Post-Denial Strategies: How to Get from "No" to "Yes," 24 Bender's Immigr. Bull. 1327, 1333 (Nov. 1, 2019). 
It is worth filing a complaint in federal district court alleging that USCIS was arbitrary and capricious in denying the $\mathrm{H}-1 \mathrm{~B}$ petition. The lawsuit itself might trigger a reopening that leads to an $\mathrm{H}-1 \mathrm{~B}$ approval. Even if the case proceeds, a federal district court judge might be more willing to reverse USCIS's denial than an AAO adjudicator.

Attorneys should file separate lawsuits for each denial, as cases vary in the strength of their facts and the complexity of relevant issues. Combining H-1B denials into a single lawsuit allows the court to focus more on facts or issues that are less advantageous to the plaintiffs.

When filing a motion for summary judgment, attorneys should raise all challenges in the motion. In Innova Solutions, the court held that USCIS was not arbitrary or capricious in finding that the plaintiff failed to prove some criteria because the plaintiff did not challenge those issues in its motion for summary judgment.

When raising the issues, include strong evidence. For example, in Innova Solutions, the court held that letters written by attorneys to establish a criterion for specialty occupation were insufficient. The court seemingly agreed with USCIS that the plaintiff did not provide "probative evidence of [its] requirements for the position such as job postings or internal position descriptions for the proffered position." 29

While USCIS may voluntarily reopen a case and grant an $\mathrm{H}-1 \mathrm{~B}$ petition in response to a lawsuit, recent cases that upheld $\mathrm{H}-1 \mathrm{~B}$ denials could decrease the likelihood of such resolutions. Courts seem to reach varying conclusions on issues regarding specialty occupation, especially when it comes to how probative the $\mathrm{OOH}$ is in determining educational requirements for specialty occupation. However, the $\mathrm{OOH}$ includes a disclaimer that the "[OOOH] is not intended to, and should never, be used for any legal purpose" and that "the information in the $\mathrm{OOH}$ should not be used to determine if an applicant is qualified to enter a specific job in an occupation." 30

To better guide courts on how to interpret the $\mathrm{OOH}$ in examining $\mathrm{H}-1 \mathrm{~B}$ denials based on $\mathrm{OOH}$ language,

29 Innova Solutions, Inc. v. USCIS, 2019 U.S. Dist. LEXIS 134790 at $* 27$.

30 Bureau of Labor Statistics, U.S. Dep't of Labor, Occupational Outlook Handbook, Disclaimer, https://www.bls.gov/ ooh/about/disclaimer.htm (last visited Nov. 15, 2019). attorneys could: (1) bring together a class of employers and beneficiaries; (2) identify potentially favorable circuits; and (3) file joint actions aimed to build case law that would foreclose USCIS's attempts to deny H$1 \mathrm{~B}$ petitions based on its erroneous interpretation of the $\mathrm{OOH}$ and the specialty occupation criteria.

$$
* * * *
$$

Hun Lee (h12346@cornell.edu) is a second-year law student at Cornell Law School.

Stephen Yale-Loehr (swy1@cornell.edu) is coauthor of Immigration Law and Procedure, the leading twenty-one-volume immigration law treatise, published by LexisNexis. He is also Professor of Immigration Practice at Cornell Law School and of counsel at Miller Mayer LLP in Ithaca, New York.

Copyright (C) 2019 Hun Lee and Stephen YaleLoehr. All rights reserved.

\section{ATTENTION READERS}

Any reader interested in sharing information of interest to the immigration bar, including notices of upcoming seminars, newsworthy events, "war stories," copies of advisory opinions, or relevant correspondence from the DHS, DOJ, DOL, or DOS should direct this information to:

Daniel M. Kowalski

Attorney \& Counselor at Law

Ware I Immigration

2305 East Arapahoe Road, Suite 100

Centennial, CO 80122

Ph: (303) 797-8055

Mobile: (512) 826-0323

E-Mail: dkowalski@david-ware.com

Follow Dan on Twitter: @dkbib

You may also contact:

Ellen Flynn, Practice Area Editor

Matthew Bender/LexisNexis

E-Mail: ellen.m.flynn@lexisnexis.com

If you are interested in writing for the BULLETIN, please contact Daniel M. Kowalski at (512) 826-0323 or via email atdkowalski@david-ware.com. 